\title{
Primary Duodenal Mucosa-Associated Lymphoid Tissue Lymphoma (MALToma): A Case Report
}

\author{
Arzu Cennet Işık, Seydahmet Akın, ${ }^{1}$ Mesut Ayer, ${ }^{2}$ Tuğba Sevinç Gamsız," \\ Begüm Damla Şencan, ${ }^{3}$ Özcan Keskin ${ }^{1}$
}

\begin{abstract}
'Department of Internal Medicine Kartal Dr. Lütfi Kırdar Training and Research Hospital, İstanbul, Turkey ${ }^{2}$ Department of Haematology, Haseki Training and Research Hospital, İstanbul, Turkey ${ }^{3}$ Department of Radiology, Karta Dr. Lütfi Kırdar Training and Research Hospital, İstanbul, Turkey

Submitted: 27.10.2017 Accepted: 25.01.2018

Correspondence: Arzu Cennet Işık, Kartal Dr. Lütfi Kırdar Eğitim Araştırma Hastanesi, İç Hastalıkları Kliniği, İstanbul, Turkey

E-mail: arzukaracelik@gmail.com
\end{abstract}

(ary

Keywords: Double contrast barium bowel graphy; duedonal lymphoma; MALToma; non-Hodgkin lymphoma.

\begin{abstract}
Primary duodenal mucosa-associated lymphoid tissue (MALT) lymphoma is the most rarely seen type of non-Hodgkin lymphoma and is diagnosed most commonly in the stomach. A 20 -year-old male patient presented with progressive vomiting, weight loss, and abdominal pain. There was nothing remarkable on 2 consecutive gastroduodenoscopies, but his complaints persisted. A double-contrast barium examination was performed, which revealed a filling defect in the duodenum. A biopsy specimen from the patient determined the presence of Helicobacter pylori and the patient was diagnosed with poorly-differentiated B-cell MALT lymphoma Successful chemotherapy and $H$. pylori eradication therapy were performed and follow-up revealed no recurrence.
\end{abstract}

\section{INTRODUCTION}

Primary lymphoma of the gastrointestinal tract seems to be the most common type of extra nodal lymphoma. It accounts for between $4 \%$ and $12 \%$ of cases of non-Hodgkin lymphoma (NHL) and it appears most often in the stomach (50-60\%) and the small intestines (30\%). ${ }^{[1-3]}$ The annual incidence of high grade NHL is $0.8-1.5$ cases $/ 100,000$ people. ${ }^{[4]}$ In the United States, it is predominantly noted at the age of 60 to 70 years with a male/female ratio of $2 / 1 .{ }^{[5]}$ In Turkey, it is diagnosed at the age of about 49 years, and men are more commonly affected. ${ }^{[6]}$ The incidence in de- veloping countries appears to be lower than in developed countries. ${ }^{[7]}$ Gastric mucosa-associated lymphoid tissue (MALT) lymphoma is usually associated with Helicobacter pylori and regression can be achieved through eradication. Extra-nodal lymphomas can arise in the ocular adnexa, the lung, the salivary gland, the thyroid, the skin, and the gastrointestinal system other than the stomach. ${ }^{\left[{ }^{8]}\right.}$ Systemic symptoms are uncommon.

\section{CASE REPORT}

A 20-year-old male patient presented at the outpatient de- 
partment of internal diseases with progressively increasing vomiting, abdominal pain, and weight loss for 3 months. He had no known illness or drug history. He described no fever nor night sweats. On physical examination, a cachexic appearance was observed and there was sensitivity in the upper left quadrant when the abdomen was palpated. No peripheral lymphadenopathy, hepato-splenomegaly, or intraabdominal mass was detected. A detailed laboratory study yielded no abnormal findings other than increased creatinine kinase. The patient was hospitalized for further examination. Gastroduodenoscopy performed at another center and at our hospital revealed antral gastritis, reflux esophagitis. Gastric biopsy specimens were positive for H. Pylori. Amoxicillin 500 mg 4xl, clarithromycin 500 $\mathrm{mg} 2 \mathrm{xl}$, and omeprazole $20 \mathrm{mg} 2 \mathrm{xl}$ were administered as eradication therapy. As there was no improvement in the nausea and vomiting despite symptomatic therapy, endoscopic re-evaluation was suggested, but the patient declined. Abdominopelvic computed tomography indicated a suspected obstruction around the third and the fourth parts of the duodenum. A double-contrast barium graphy revealed a regular mass measuring $25-\mathrm{mm}$ in diameter in the second post bulbar duodenal quadrant, narrowing the lumen (Fig. I). Simultaneous Doppler ultra-sonographic examination showed a hypervascular mass, initially suggesting a neoplasm, and numerous micro-lymphadenopathies adjacent to the serosa (Fig. 2). Surgery under general anesthesia was performed to obtain a biopsy sample and simultaneous histopathological examination of the specimen revealed poorly differentiated B-cell MALT lymphoma. A bone marrow biopsy was characterized by normal cellular hematopoietic cells. The Ehrlich-ZiehlNeelsen test for lymphadenopathies was negative and there was no growth in a Lowenstein tuberculosis culture. The patient received 6 cycles of CHOP (cyclophos-
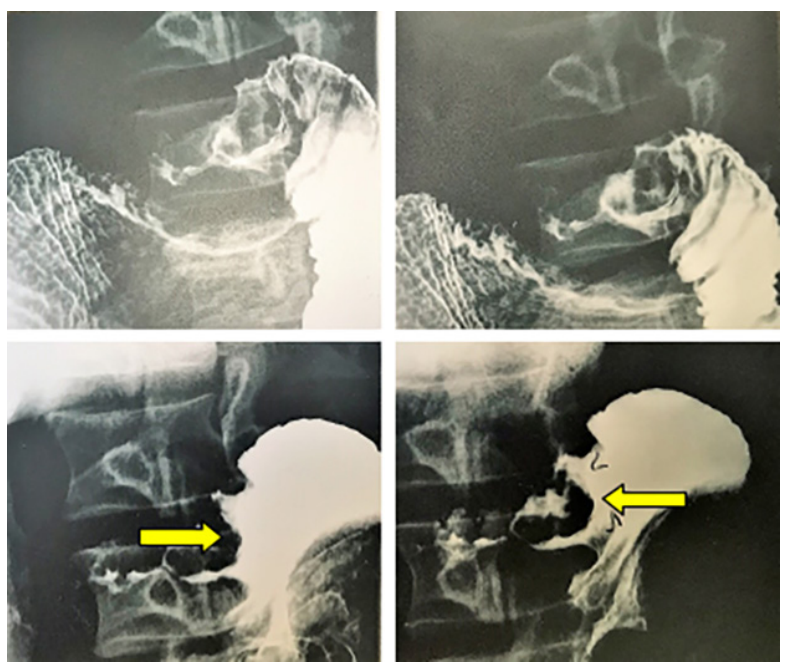

Figure 1. A double-contrast barium graphy revealed a regular mass measuring 25-mm in diameter in the second post bulbar duodenal quadrant, narrowing the lumen.

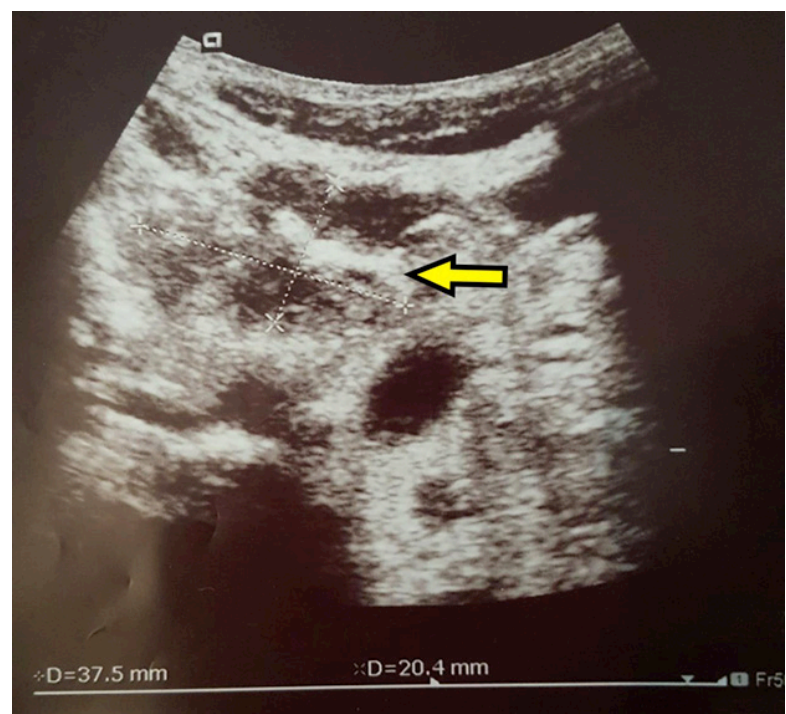

Figure 2. Doppler ultrasonography showed a hypervascular mass.

phamide, doxorubicin, vincristine, and prednisone) and $H$. pylori eradication therapy. A urea breath test was negative for $H$. pylori. The patient was discharged. Two years of follow-up at the outpatient department of the hematology indicated that he had achieved remission.

\section{DISCUSSION}

MALT lymphomas are the most frequently encountered lymphomas of the gastrointestinal system and the stomach is the most common location. Of the lymphomas of the gastrointestinal tract, the prognosis for duodenal lymphomas is poor compared with other intestinal lymphomas and genetic predisposition has not been detected. The stage at diagnosis is the guideline for prognosis. ${ }^{[3]}$ Although the association of $H$. pylori with gastric lymphomas has been identified, this relationship has not fully been established in duodenal lymphomas. $H$. pylori eradication is critical in the treatment of MALT lymphoma and can lead to regression of lymphoma. ${ }^{[9,10]} \mathrm{H}$. pylori-induced gastritis first leads to the accumulation of CD4+ lymphocytes and mature $B$ cells in the gastric lamina propia. Antigens derived from $H$. pylori drive the activation of $\mathrm{T}$ cells, $B$ cell proliferation, and lymphoid follicle formation, which can evolve into a monoclonal lymphoma.

Lepicard et al. ${ }^{\left[{ }^{11]}\right.}$ administered oral cyclophosphamide in 4 cases of duodenal MALT lymphoma and reported that it could be a preferred treatment of this disease with slow progression. Ochi et al. ${ }^{[12]}$ reported that they administered clarithromycin in the treatment of MALT lymphoma limited to the mucosa and submucosa, which led to regression. They reported that they achieved successful long-term results utilizing the inhibitory effect of clarithromycin on lymphoid activation. In recent years, studies 
have demonstrated successful treatment results with antitumor necrosis factor drugs aside from CHOP. Current chemotherapy techniques and a new generation of agents can achieve long-term remission. ${ }^{[13,14]}$

Endoscopic examination usually leads to diagnosis in cases with clinically suspected lymphomas of the gastrointestinal tract. However, a barium examination (double-contrast small bowel graphy) may be helpful in leading to the diagnosis if the endoscopic procedure fails or cannot be tolerated. We wanted to share this case since it is rarely encountered and difficult to diagnose, and because complete remission was achieved for 2 years.

\section{Informed Consent}

Approval was obtained from the patients.

Peer-review

Internally peer-reviewed.

Authorship Contributions

Concept: A.C.I., S.A., M.A., Ö.K.; Design: A.C.I., S.A., M.A., Ö.K.; Analysis and/or interpretation: A.C.I., S.A., M.A., T.S.G., B.D.Ş., Ö.K.; Literature search: A.C,I., S.A., T.S.G., B.D.Ş.; Writing: A.C.I., T.S.G.; Critical review: A.C.I., S.A., M.A., T.S.G., B.D.Ş., Ö.K.

Conflict of Interest

None declared.

\section{REFERENCES}

1. Woo KH, Kim JH, Yoon SB, Jang JH, Lee DH, Hong SH, et al. Duodenal mucosa-associated lymphoid tissue lymphoma: a case report. Korean J Intern Med 2007;22:296-9. [CrossRef]

2. Radaszkiewicz T, Dragosics B, Bauer P. Gastrointestinal malignant lymphomas of the mucosa-associated lymphoid tissue: factors relevant to prognosis. Gastroenterology 1992;102:1628-38. [CrossRef]

3. Najem AZ, Porcaro JL, Rush BF Jr. Primary non-Hodgkin's lymphoma of the duodenum. Case report and literature review. Cancer 1984;54:895-8. [CrossRef]

4. Leone N, Brunello F, Baronio M, Giordanino C, Morgando A,
Marchesa P, et al. High-grade B-cell lymphoma arising in mucosaassociated lymphoid tissue of the duodenum. Eur J Gastroenterol Hepatol 2002;14:893-6. [CrossRef]

5. Eser B. Proceeding Book 38. National Heamotology Congress 31 October-3 December. Antalya, Turkey.

6. Eser B, Kaplan B, Unal A, Canoz O, Altuntas F, Sari HI, et al. Clinicopathologic characteristics and therapeutic outcomes of primary gastrointestinal non-Hodgkin's lymphomas in central Anatolia, in Turkey. Yonsei Med J 2006;47:22-33. [CrossRef]

7. Perry AM, Diebold J, Nathwani BN, MacLennan KA, Müller-Hermelink HK, Bast M, et al. Non-Hodgkin lymphoma in the developing world: review of 4539 cases from the International Non-Hodgkin Lymphoma Classification Project. Haematologica 2016;101:124450. [CrossRef]

8. Freedman AS, Aster JC. Clinical manifestations, pathologic features, and diagnosis of extranodal marginal zone lymphoma of mucosa associated lymphoid tissue (MALT). UpToDate2017.

9. Nagashima R, Takeda H, Maeda K, Ohno S, Takahashi T. Regression of duodenal mucosa-associated lymphoid tissue lymphoma after eradication of Helicobacter pylori. Gastroenterology 1996;111:1674-8.

10. Xiang Z, Onoda N, Ohira M, Yukawa T, Uchida T, Arakawa T, et al. Mucosa-associated lymphoid tissue lymphoma of the duodenum: report of a case resistant to Helicobacter pylori eradication. Hepatogastroenterology 2004;51:732-5.

11. Lepicard A, Lamarque D, Lévy M, Copie-Bergman C, Chaumette MT, Haioun C, et al. Duodenal mucosa-associated lymphoid tissue lymphoma: treatment with oral cyclophosphamide. Am J Gastroenterol 2000;95:536-9. [CrossRef]

12. Ochi M, Tominaga K, Okazaki H, Yamamori K, Wada T, Shiba M, et al. Regression of primary low-grade mucosa-associated lymphoid tissue lymphoma of duodenum after long-term treatment with clarithromycin. Scand J Gastroenterol 2006;41:365-9. [CrossRef]

13. Juanmartiñena Fernández JF, Albéniz E, Fernández-Urién I, Montes Díaz M, Vila Costas JJ. Primary MALT lymphoma of the duodenum. Med Clin (Barc) 2017;148:e47.

14. Seki A, Iwamuro M, Yoshioka M, Fujii N, Okada H, Nose S, et al. Primary Duodenal Follicular Lymphoma Treated With Rituximab Monotherapy and Followed-up for 15 Years. Acta Med Okayama 2015;69:301-6.

\section{Primer Duedonal Mukoza Kökenli Lenfoid Doku Lenfoması (MALToma): Olgu Sunumu}

Primer duodenal MALT (Mucosa Associated Lymphoid Tissue) lenfoma non-Hodgkin lenfomanın (NHL) nadir görülen bir türüdür ve en sık midede saptanmaktadır. Yirmi yaşında erkek hastamız; progresif şekilde kusma, kilo kaybı ve karın ağrısı nedeniyle tarafımıza başvurdu. İki kez yapılan gastroduodenoskopide belirgin özellik olmaması ve şikayetlerinin devamı üzerine istenen çift kontrast baryum incelemesinde duodenumda dolum defekti saptandı. Helicobacter pylori pozitifliği de bulunan hastadan alınan biyopsi örneğinde kötü diferansiye B hücreli MALT lenfoma teşhisi konuldu.

Anahtar Sözcükler: Çift kontrast baryum incelemesi; duedonal lenfoma; MALToma; non-Hodgkin lenfoma. 